\title{
TERAPI ALTERNATIF PENGURANGAN RASA NYERI DAN KECEMASAN MELALUI SLOW STROKE BACK MASSAGE (SSBM) PADA INPARTU KALA I FASE AKTIF
}

\author{
DIAH EVAWANNA ANUHGERA ${ }^{1}$,WILDA WAHYUNI SIREGAR ${ }^{2}$, \\ NIKMAH JALILAH RITONGA ${ }^{3}$, DESIKA WALI PARDEDE ${ }^{4}$ \\ 1,2,3,4Institut Kesehatan Medistra Lubuk Pakam \\ Jl. Jendral Sudirman no 38 Lubuk Pakam \\ e-mail :diah.evawanna@gmail.com
}

DOI : https://doi.org/10.35451/jkk.v2i2.398

\begin{abstract}
Labor is always synonymous with the experience of pain and fear felt by mother. SSBM stimulates the body release endorphins which are having natural pain killing propoerties and reducing anxiety levels. This study aimed to determine the effect of slow stroke back massage (SSBM) on reduction of labor pain and anxiety during first stage of labor. A quasi-experimental study with purposive non-probability sampling techniwue is used for the people. Study was conducted on 36 samples (18 in experimental group anda 18 in control group). A structured interview schedule, albor assesment performa, numerical pain rating scale and DASS(Depresssion, Anxiety and Stress Scales) were used for data collection and the data were analyzed by paired and unpaired t test. There were statistically significant differences of anxiety and pain levels before and after intervention in the experiment and control group with $p$ value 0.00. Result confirmed that SSBM is significantly effective in reducing labor pain and anxiety level during first stage of labor.
\end{abstract}

Keywords:Labor pain, Anxiety, Slow Stroke Back Massage

\section{Pendahuluan}

Kelahiran anak adalah proses biologis alami dan oleh karena itu rasa sakit yang terkait dengannya juga dianggap normal dan alami. Sifat rasa sakit yang dialami selama persalinan tergantung pada status fisik dan emosional wanita. Nyeri persalinan adalah rasa sakit yang tak tertahankan yang luar biasa, yang menghasilkan perubahan tekanan darah, denyut nadi, pernapasan, warna kulit, pucat dan diaforesis. Wanita dengan nyeri persalinan mungkin mengalami mual dan muntah, cemas dan takut pada proses persalinannya
Seorang wanita yang mengalami rasa sakit saat melahirkan anak adalah pengalaman unik yang dapat diingat di dalam kehidupannya. Sebagian besar para ibu menyatakan bahwa persalinan adalah situasi yang jauh lebih menyakitkan dan penuh tekanan, sebagian besar dirasakan lebih tinggi pada ibu primigravida daripada multipara (Fitri, 2018).

Kuriakose D. A. 2012 menyatakan bahwa ibu primigravida tidak tahu mana yang merupakan rasa sakit yang hebat dan bagaimana mengatasinya karena mereka tidak memiliki pengalaman masa lalu untuk ibu primigravida ini adalah persalinan 
pertama, ibu mengalami banyak rasa sakit bila dibandingkan dengan multipara.

Pada tahap pertama persalinan ada dua fase, yang meliputi fase latendan fase aktif. Fase laten sebelum fase pertama persalinan aktif dan dapat berlangsung 6-8 jam dengan dilatasi serviks 0 hingga $3 \mathrm{~cm}$. Fase aktif adalah tahap persalinan ketika serviks dilatasi $4 \mathrm{~cm}$ sampai sepenuhnya dilatasi dengan peningkatan kontraksi uterus (Gill, T et al 2019).

Rasa sakit itu sendiri dan keparahannya, ditambah efek samping dari obat, membuatnya wanita kesulitan untuk mempertahankan kontrol selama persalinan. Wanita kemudian membutuhkan perawatan, dukungan, perhatian dan saran pada kondisi ini. Oleh karena itu bidan diminta untuk memberikan kontrol rasa sakit pada wanita daripada memberantasnya dan harus dilakukan pembedaan yang jelas antara tujuan tradisional pereda nyeri dan kontrol nyeri pada persalinan.

Menurut Nikula P (2015) menyatakan proses kelahiran sering menjadi hal yang sakit, tegang dimana wanita merasa lelah, takut, dan perasaan negatif akan persalinannya dan mengakhiri persalinannya dengan seksio sesarea. Kecemasan merupakan dampak dari rasa sakit yang dialami oleh wanita sehingga membuat semua hal positif di dalam pikirannya menjadi hilang dan menganggap kelahirannya akan menimbulkan ketakutan (Nikula $P, 2015$ )

Kecemasan dapat menimbulkan rasa takut, mempengaruhi kemajuan dari persalinan. Hal itu tentu saja dapat memberikan dampak buruk pada peningkatan tindakan seksio sesarea. Menurut Chauhan pada tahun 2016 menyatakan $60 \%$ primipara dan $40 \%$ multipara mengalami kontraksi persalinan yang yang sangat kuat pada fase laten dan menurut survey yang ada terdapat $40 \%$ yang takut akan proses persalinan.

Ada banyak jenis metode pengendalian nyeri non-farmakologis; di antaranya, homeopati, hidroterapi, terapi musik, TENS, teknik akupresur, penerapan panas \& dingin, dan pijat adalah teknik yang paling umum dan banyak diterapkan (Gill, T et al 2019). Slow Stroke Back Massage (SSBM) adalah salah satu teknik pijat untuk persalinan, yang digunakan selama tahap awal persalinan (Mortazavi, 2012).

Teknik pijat ini dirancang khusus di mana stroke melingkar ke atas dan ke bawah diberikan pada kedua sisi tulang belakang di daerah sakral dengan pernapasan terkontrol, yang membantu mengurangi intensitas nyeri persalinan. Dibandingkan dengan semua metode non-farmakologis dari penghilang rasa sakit selama ini, metode SSBM memiliki manfaat penting seperti: non invasif, tidak memberikan efek berbahaya bagi ibu maupun janin, dapat dilakukan dengan mudah dan dapat mengurangi kebutuhan obat farmakologi untuk pereda sakit (Mortazavi, 2012).

Pijatan SSBM dimulai dari bagian punggung dengan tekanan yang lambat, lembut. Pijatan dimulai dari bagian posterior pada punggung berirama dan lembut pada punggung pasien dengan kecepatan 60 gerakan dalam satu menit selama 15 menit (Elkheshen S.A, 2017).

Berbagai penelitian menyatakan manfaat dari SSBM yaitu menurunkan nyeri, relaksasi, penurunan tekanan darah, kecemasan, dan denyut nadi. Pada penelitian lainnya waktu pelaksanaan SSBM untuk menurunkan nyeri persalinan belum dinyatakan secara jelas sehingga peneliti memutuskan pada penelitian ini melakukan terapi SSBM ini selama 15 
menit dari beberapa jurnal yang telah dikaji peneliti (Mortazavi, 2012).

Dari hasil wawancara ke 5 ibu hamil yang mendekati hari perkiraan kelahirannya menyatakan bahwa salah satu hal yang paling ditakuti adalah rasa sakit sewaktu persalinan yang membuat ketidaknyamanan. Untuk alasan ini, peneliti merasa penting untuk mempelajari efek metode SSBM pada pengurangan nyeri persalinan dan kecemasan pada proses persalinan kala I fase aktif.

Tujuan penelitian ini adalah untuk mengetahui efektifitas metode Slow Stroke Back Massage (SSBM) terhadap nyeri dan kecemasan pada persalinan kala I fase aktif.

\section{METODE}

Penelitian ini menggunakan desain penelitian kuasi eksperimen dengan tipe two group pretest and post test. Penelitian ini dilaksanakan pada Juli 2019 hingga Oktober 2019 di Praktik Bidan Mandiri Nining di Lubuk Pakam, Kabupaten Deli SerdangSumatera Utara. Formulir inform consent disiapkan untuk setiap responden penelitian dan peneliti akan menjelaskan tujuan dari penelitian yang dilakukan pada kelompok intervensi dan kontrol.

Sampel pada penelitian ini adalah seluruh ibu inpartu kala I fase aktif primigravida yang akan melahirkan di Praktik Bidan Mandiri Nining sebanyak 36 orang yang terbagi dua kelompok yaitu 18 orang kelompok intervensi dan 18 orang kelompok kontrol. Teknik pengambilan sampel berupa purposive sampling.

Kriteri inklusi pada penelitian ini diantaranya: wanita primigravida berusia 16-35 tahun, berada pada fase kala aktif pembukaan $4 \mathrm{~cm}$, mengalami kehamilan normal tanpa komplikasi, usia kehamilan 37-40 minggu, dilatasi serviks lebih dari $3 \mathrm{~cm}$. Kriteria eksklusi adalah pemberian infus oksitosin untuk percepatan proses persalinan, ibu yang memiliki ganguan otot, ibu yang berencana untuk melakukan persalinan seksio sesarea.

Proses penelitian pada penelitian ini diawali dari pengelompokan pasien berdasarkan kriteria inklusi dan eksklusi, membagi kelompok secara acak menjadi 2 kelompok yaitu kelompok intervensi dengan pemberian metode SSBM dan kelompok kontrol diberikan perawatan kebidanan standar untuk penangan nyeri pada proses persalinan. Sampel dari masing-masing kelompok tidak mengetahui adanya perbedaan intervensi yang diberikan.

Prosedur slow stroke back massage diantaranya yaitu: meletakkan ibu pada posisi lateral kiri, pastikan tangan dalam kondisi hangat dan nyaman, ambil 2 tetes dan tempatkan di telapak tangan menghadap pinggul ibu dengan ujug jari menghadap ke atas. Gerakkan kedua telapak tangan secara bersamaan dari tepi bergerak ke atas hingga level $\mathrm{T} 10$ dan perlahan-lahan kemudian turun. Pada saat pemijatan gunakan ibu jari dan pijat area punggung membentuk melingkar dari bawah ke atas. Ulangi pemijatan hingga 3 sampai 5 kali SSBM dilakukan kepada ibu selama 30 menit. Sebelum dan sesudah dilakukan pemijatan peneliti melakukan pretest berupa manilai tingkat nyeri ibu menggunakan skala NRS (Numeric Rating Scale) dan tingkat kecemasan menggunakan skala DASS (Depression, Anxiety and Stress Scales). Analisa data pada penelitian ini menggunakan paired dan unpaired $t$ test 


\section{HASIL}

Tabel 1 menunjukkan bahwa rerata nyeri persalinan sebelum dilakukan intervensi pada kelompok intervensi (pemberian metode SSBM) sebesar $7.50 \pm 0.514$ dan mengalami penurunan menjadi $6.44 \pm 0.511$. Sedangkan pada kelompok kontrol, rerata nyeri persalinan sebelum dilakukan intervensi pada kelompok kontrol yaitu $7.33 \pm 0.686$ dan mengalami penurunan menjadi 7.11 \pm 0.758 . Hasil uji statistik pada kelompok kontrol dan intervensi diperoleh nilai $\mathrm{p}=0.00$ maka dapat disimpulkan terdapat perbedaan yang signifikan sebelum dan setelah dilakukan intervensi pada kelompok kontrol dan intervensi.
Penilaian rerata kecemasan pada ibu inpartu kala I fase aktif menunjukkan penurunan setelah dilakukan intervensi berupa SSBM yaitu $27.17 \pm 1.581$ menjadi $25.89 \pm 1.410$, dengan nilai $p=0.00$ yang artinya ada perbedaan yang signifikan sebelum dan sesudah dilakukan metode SSBM untuk menurunkan rerata kecemasan pada ibu inpartu kala I fase aktif.

Sedangkan pada kelompok kontrol tidak terdapat perbedaan yang signifikan pada nilai rerata kecemasan ibu inpartu kala I fase aktif. Rerata kecemasan pada kelompok kontrol pada kondisi awal 25.89 \pm 1.410 meningkat menjadi $26.22 \pm 1.957$.

Tabel 1. Perbedaan Rerata Nyeri Persalinan dan Kecemasan pada Inpartu Kala I Fase Aktif Sebelum dan Sesudah Intervensi pada Kelompok Kontrol dan Intervensi

\begin{tabular}{cccccccc}
\hline \multicolumn{2}{c}{ Variabel } & \multicolumn{2}{c}{ Pretest } & \multicolumn{2}{c}{ Posttest } & $\mathrm{t}$ & $\mathrm{p}$ \\
\cline { 2 - 6 } $\begin{array}{c}\text { Nyeri } \\
\text { Persalinan }\end{array}$ & $\begin{array}{c}\text { Inter } \\
\text { vensi }\end{array}$ & 7.50 & 0.514 & 5.44 & 0.511 & 10.761 & 0.000 \\
\cline { 2 - 7 } & Kontrol & 7.33 & 0.686 & 7.11 & 0.758 & 2.204 & 0.042 \\
\hline Kecemasan & $\begin{array}{c}\text { Inter } \\
\text { vensi }\end{array}$ & 27.17 & 1.581 & 24.61 & 2.062 & 8.382 & 0.000 \\
\cline { 2 - 6 } & Kontrol & 25.89 & 1.410 & 26.22 & 1.957 & -8.09 & 0.430 \\
\hline
\end{tabular}

Tabel 2.Perbedaan Nyeri Persalinan pada Inpartu Kala I Fase Aktif Sesudah Intervensi pada Kelompok Kontrol dan Intervensi Variabel Mean SD Mean Difference $\mathrm{p}$

\begin{tabular}{lccccc}
\hline Nyeri & Intervensi & 6.44 & 0.511 & 1.89 & 0.000 \\
\cline { 2 - 4 } Persalinan & Kontrol & 7.33 & 0.767 & & 0.022 \\
\hline $\begin{array}{l}\text { Kecema } \\
\text { san }\end{array}$ & Intervensi & 24.61 & 2.062 & 1.61 & \\
\cline { 2 - 4 } & Kontrol & 26.22 & 1.957 & & \\
\hline
\end{tabular}

Tabel 2 menyatakan bahwa
rerata nyeri persalinan setelah dilakukan intervensi $6.44 \pm 0.511$ lebih rendah dibandingkan kelompok kontrol 7.33 \pm 0.76. Perbedaan nyeri antar kelompok intervensi dan kontrol sebesar 0.889 dengan nilai $\mathrm{p}=0.00$, artinya perbedaan rerata nyeri persalinan yang signifikan antara kelompok intervensi dan kontrol.

Rerata kecemasan ibu setelah dilakukan intervensi 24.61 2.062 lebih rendah dibandingkan kelompok kontrol sebesar $26.22 \pm 1.957$ dengan perbedaan rerata sebesar 1.61 dengan nilai $p=0.022$ artinya ada perbedaan rerata kecemasan yang signifikan antara 
kelompok intervensi dan kelompok kontrol.

\section{Konsep persalinan yang}

nyaman adalah persalinan dengan kontraksi, tetap merasakan sakit, karena rasa sakit saat melahirkan adalah sifat alami. Setiap ibu yang menghadapi proses persalinan seharusnya memiliki wawasan tentang rasa sakit saat persalinan dan mengetahui teknik alternatif yang dapat digunakan oleh ibu untuk mengatasi atau mengurangi nyeri persalinan yang akan dirasakan.

Persepsi dan pengalaman nyeri pada persalinan menjadi salah satu penyebab para ibu untuk khawatir terhadap apa yang akan terjadi pada proses persalinannya. Penelitian Kuriakose tahun 2012 menyatakan bahwa persepsi persalinan nyeri dipengaruhi oleh umur, pendidikan, suku dan pendampingan saat persalinan. Nyeri yang berlebihan dapat menghambat terjadinya persalinan yang nyaman hingga proses menyusui. Hasil penelitian DE Anuhgera tahun 2018 menyatakan bahwa akibat trauma nyeri pada persalinan dapat memberikan efek negatif hingga pada proses menyusui bayi. Ibu merasa cemas, takut, tidak percaya diri sehingga membuat produksi ASI menjadi terhambat.

Pada penelitian ini, pada kelompok intervensi dengan pemberian metode SSBM diberikan 3 kali selama 15 menit kepada setiap pasien. Pijatan dilakukan dengan lembut dan lambat pada area torakal 10 sampai 12 dan lumbal 1 . Pijatan yang berirama dan sirkuler dengan kecepatan 60 kali usapan per menit selama 15 menit. Pijatan SSBM yang dilakukan peneliti dapat membuat responden menjadi lebih nyaman setelah memperoleh pijatan, lebih tenang dan senang. Perasaan cemas yang muncul di awal persalinan perlahan-lahan berkurang menjadi tenang dan bahagia menyambut kelahiran bayinya.

Rerata nyeri posttest dari ibuibu primigravida yang memperoleh metode Slow Stroke Back Massage (SSBM) pada pengurangan nyeri secara signifikan lebih rendah daripada kelompok kontrol yang tidak diberikan metode SSBM. Metode pijatan SSBM akan memberikan manfaat pada saraf simpatik dan parasimpatif sehingga menimbulkan kenyamanan pada ibu. Pada kondisi seperti itu ibu dan keluarga bersedia mengetahui prosedur yang akan dilakukan kepadanya dan mengerti akan manfaat yang akan diperoleh sehingga rasa sakit dapat menjadi lebih rendah dibandingkan kelompok kontrol.

Efek pijatan SSBM mengacu pada pengaruh stimulasi sistem saraf secara otomatis dari berbagai area tubuh. Pijatan lembut merangsang respons parasimpatis, sedangkan pijatan yang rendah dapat merangsang respons sistem saraf simpatis (Babajani S, 2014). Adanya kontak antara tubuh pasien dan tangan peneliti selama terapi pijat dapat menyebabkan pengurangan kecemasan, penurunan nyeri, tekanan darah dan denyut nadi (Zadkhosh SM,2015).

Peng et al (2015) menyatakan bahwa pijatan mengurangi emosi gugup dan memberikan keseimbangan besar antara aktivitas sistem saraf parasimpatis dan simpatis (35). Pijat dapat meningkatkan tekanan pada jaringan, sehingga, gradien tekanan akan meningkat antara jaringan dan pembuluh darah. Hal ini dapat menyebabkan pergerakan cairan antara jaringan dan pembuluh darah yang mengatur tekanan darah 
sehingga kecemasan pada ibu dapat menurun.

Hal ini sejalan dengan Chauhan K(2016) dalam penelitian terhadap 60 wanita yang mengalami nyeri pada persalinan tahap pertama, mengatakan ada penurunan efek pijat pada nyeri persalinan. Chauhan $\mathrm{K}$ (2016) juga menyatakan persalinan adalah pengalaman yang spesial dan unik untuk setiap wanita. Rasa sakit, kelelahan, dan ketakutan baik secara fisik maupun psikologis. Nyeri adalah pengalaman umum yang akan dirasakan oleh wanita yang melahirkan. Pengurangan rasa sakit dapat diharapkan teknik relaksasi dapat meningkatkan toleransi rasa sakit, pengurangan kecemasan dan penurunan ketegangan otot. Relaksasi dapat ditingkatkan melalui konsentrasi pada pola tertentu, pijatan selama kontraksi adalah aktivitas kognitif yang paling sukses sebagai strategi manajemen nyeri non-medis.

Seperti yang dinyatakan Mortazavi (2012), kecemasan dan ketakutan dalam menghadapi persalinan akan menambah rasa sakit. Kecemasan akan meningkatkan respons individu terhadap rasa sakit, ketidaksiapan menghadapi persalinan. Ketakutan akan hal yang tidak diketahui, pengalaman buruk saat melahirkan yang lalu, dukungan dan fasilitasi persalinan yang tidak baik juga akan menambah kecemasan yang mengakibatkan peningkatan rangsangan nosiseftif pada tingkat korteks serebral dan peningkatan sekresi katekolamin, dan juga peningkatan nosiseftif rangsang panggul karena penurunan aliran darah dan ketegangan otot.

Pijat SSBM (Slow Storoke Back Massage) merupakan metode pijat yang efektif untuk menurunkan nyeri persalinan, membuat otot-otot menjadi rileks. Beberapa penelitian menyatakan bahwa setiap orang menyatakan sangat nyaman setelah dilakukan pijatan, mengurangi rasa sakit. Pada penelitian ini, hal tesebut juga dialami oleh sebagian besar responden ibu inpartu yang menyatakan bahwa sensasi rasa nyeri yang timbul ketika proses persalinan berkurang, menjadi lebih nyaman dan tenang setelah dilakukan pijatan SSBM. Pijatan dengan metode SSBM akan menyebabkan transmisi saraf sensorik A-Beta sebagai pemancar neuro sehingga mnegurangi transmisi nyeri dan menutup sinaps nyeri . Dan dengan pijatan di area punggung belakang akan memicu pengeluaran hormon endorpin sehingga membuat perasaan menjadi nyaman dan tenang (Unalmis E.S, dan Elkheshen S.A 2017).

Studi ini juga konsisten dengan teori Gate Control yang membawa serat nyeri ke stimulasi otak lebih sedikit rasa sakit dan sensasi bepergian lebih lambat daripada serat yang disentuhnya lebar. Ketika sentuhan dan rasa sakit dirangsang secara bersamaan, sensasi sentuhan ke otak akan menutup gerbang di otak mengakibatkan pembatasan rasa sakit di otak (Elkheshen S.A 2017).

Fitri (2018) melakukan penelitian yang serupa dengan jumlah sampel sebanyak 30 orang dibagi menjadi 2 kelompok, pijatan, pemberian SSBM dan kelompok kontrol. Hasil penelitian Sasrawita menyatakan ada perbedaan signifikan penurunan intensitas nyeri sebelum (6.43) dan sesudah pijat (4.13). Pijat dapat disimpulkan efektif dalam mengurangi nyeri persalinan dibandingkan dengan kelompok kontrol.

Beberapa penelitian lain juga menunjukkan banyak manfaat dari metode pijat ini. Selain membantu 
mengurangi rasa sakit ibu, pijatan juga dapat digunakan sebagai metode alternatif untuk mengurangi durasi persalinan, kadar kortisol dan kecemasan selama persalinan.

Hasil penelitian Dreyer et al. (2015) menyatakan bahwa pijat Swedia dapat menurunkan kecemasan, relaksasi, dan ketegangan selama 3 hari setelah operasi kolorektal. Hasil penelitian menunjukkan bahwa pijat Swedia mengurangi kecemasan dan parameter fisiologis secara signifikan pada pasien. Dalam penelitian itu, ukuran sampel yang tinggi dan kinerja pijat oleh terapis pijat dengan pelatihan khusus dan pengalaman bekerja di rumah sakit dapat menjadi penyebab efek positif pijat pada karakteristik psikologis dan parameter fisiologis.

Efek berbeda dari terapi pijat dalam penelitian ini dapat dikaitkan dengan pijat yang dilakukan oleh peneliti. Namun, hasilnya mungkin berbeda jika pijatan yang sama dilakukan oleh ibu. Ada kemungkinan bahwa pijatan selama lebih dari tiga hari dapat memiliki efek yang berbeda dari yang diamati dalam penelitian ini. Kami merekomendasikan penelitian lebih lanjut untuk mengeksplorasi apakah kinerja SSBM oleh ibu mungkin mengungkapkan efek positif pada kecemasan dan parameter fisiologis pada anak yang dirawat di rumah sakit untuk perawatan.

Beberapa responden pada penelitian ini merasakan penurunan nyeri persalinan yang tidak terlalu signifikan. Ada yang menyatakan karena tidak ada pengalaman persalinan, tidak didampingi suami. Peneliti menyimpulkan bahwa nyeri dipengaruhi oleh kecemasan, dukungan persalinan, primigravida dan lingkungan yang membuat ibu merasa nyaman.
Pada kelompok kontrol terdapat perbedaan rerata nyeri sebelum dan sesudah dilakukan intervensi berupa pelayanan kebidanan sesuai standar praktik kebidanan. Hal ini dipengaruhi oleh informasi pengetahuan akan kehamilan, persalinan yang banyak dan motivasi persalinan normal yang kuat dari ibu dan lingkungan yang mendukung meliputi keluarga dan penolong persalinan.

\section{KESIMPULAN}

Hasil penelitian ini menunjukkan bahwa Slow Stroke Back Massage (SSBM) efektif dalam mengurangi nyeri persalinan pada kala I fase aktif selama 15 menit dengan nilai $p$ value 0.00 . Sedangkan untuk variabel kecemasan menunjukkan ada perbedaan bermakna antara sebelum dan sesudah intervensi SSBM terhadap rerata kecemasan pad persalinan inpartu kala I fase aktif.

SSBM efektif digunakan untuk menurunkan nyeri dan kecemasan pada proses persalinan inpartu kala I fase aktif. Disarankan kepada ibu bersalin dan para bidan untuk dapat menerapkan metode ini dalam penanganan nyeri dan kecemasan pada ibu bersalin.

\section{DAFTAR PUSTAKA}

DE Anuhgera et al. 2019.Pengeluaran Kolostrum dengan Pemberian Perawatan Payudara dan Endorphin Massage pada Ibu Post Seksio Sesarea. Jurnal Penelitian Kebidanan \& Kespro. Vol2(1), 35-40.

Babajani.,S., Babatabar.,H., Ebadi., A., Mahmoudi.,H., Nasiri.,E.2014. The Effect Of 
Foot Reflexology Massage On The Level Of Pain During Chest Tube Removal After Open Heart Surgery. Iran J Critic Care Nurs,7(1),15-22.

Chauhan K, Rani S, dan Bansai P. 2016.Effectiveness of Olive Oil Back Massage on Reduction of Labor Pain during First Stage of Labor.International Journal Nursing Midwive Res.3 (2),3136.

Dahlan., S., M. (2013). Besar sampel dan Cara Pengambilan Sampel. Jakarta : Salemba Medika.

Dreyer et al.2015.Effect Of Massage Therapy On Pain, Anxiety, Relaxation, And Tension After Colorectal Surgery: $A$ Randomized Study. Complement Ther Clin Pract, 21(3), 154-9

Elkheshen.,S..A., Ahmed.,S.,S., dan Abdelgawad.,H..A, .2017. The Impact of Slow Stroke Back Massage on Anxiety Level of Low Risk Parturient Mothers in the Fourth Stage of Labor.International Journal of Nursing Didactics,7(3),51-56.

Fitri.,L., Noviawanti ., R., Sasrawita .2018.Efektivitas Stimulasi Slow Stroke Back Massage terhadap Penurunan Intensitas Nyeri Bersalin.3 (2), 232-237.

Gill., $T$ et al.2019.Women Experiences of Pharmocological and Non Pharmachological Pain Relief Methods for Labour and Childbirth: A Qualitative Systematic Review. Reproductive Health, 16(71).120.

Ko YL, Lee HJ.2014 Randomised controlled trial of the effectiveness of using back massage to improve sleep quality among Taiwanese insomnia postpartumwomen.
Midwifery.30(1):60-4. doi: 10.1016/j.midw.2012.11.005.

Kuriakose D. A.2012. Study To

Evaluate The Effectiveness of Olive Oil Back Massage On Labor Pain And Progressmin First Stage Of Labor Among Primipara Mothers. Indian Journal of Nursing and Midwifery Research, 88-90

Mortazavi S.H et al.2012.Effects of Massage Theraohy Adnd Presence Of Attendat Of Pain, Anxiety And Satisfaction During Labor. Jurnal Arch Gynecol Obstet, 286, 19-23.

Nikula $\mathrm{P}$, Laukkala $\mathrm{H}$, Pölkki T. 2015.Mothers' Perceptions of Labor Support. MCN:The American Journal of Maternal Child Nursing,40(6),373-80.

Peng S, Ying B, Chen Y, Sun X.2015 Effects Of Massage On The Anxiety Of Patients Receiving Percutaneous Coronary Intervention. Psychiatr Danub, 27(1),44-9.

Sng $\mathrm{BL}$, et al. 2018. Incidence And Risk Factors For Epidural

Re-Siting In Parturients With Breakthrough Pain During Labour Epidural

Analgesia: A Cohort Study. Int J Obstet Anesth, 34,28-36.

Unalmis Erdogan S, Yanikkerem E, Goker A.2017. Effects Of Low Back Massage On Perceived Birth Pain And Satisfaction. Complement Ther Clin Pract,28 ,169-175.

Zadkhosh SM, Ariaee E, Atri A, Rashidlamir A, Saadatyar A.2015. The Effect Of Massage Therapy On Depression, Anxiety And Stress In Adolescent Wrestlers. Inter J of Sport Std,5(3),321-7. 